\title{
From stem cells to beta cells: new strategies in cell therapy of diabetes mellitus
}

\author{
B.Soria ${ }^{1}$, A.Skoudy ${ }^{2}$, F.Martín ${ }^{1}$ \\ ${ }^{1}$ Institute of Bioengineering, University Miguel Hernández, Alicante, Spain \\ ${ }^{2}$ Municipal Institute of Medical Research, University Pompeu Fabra, Barcelona, Spain
}

\begin{abstract}
Islet transplantation as a potential treatment for diabetes has been investigated extensively over the past 10 years. Such an approach, however, will always be limited mainly because it is difficult to obtain sufficiently large numbers of purified islets from cadaveric donors. One alternative to organ or tissue transplantation is to use a renewable source of cells. Stem cells are clonogenic cells capable of both self-renewal and multilineage differentiation. These cells have the potential to proliferate and differentiate into any type of cell and to be genetically modified in vitro, thus providing cells which can be isolated and used for transplantation. Recent studies have given well-
\end{abstract}

defined differentiation protocols, which can be used to guide stem cells into specific cell lineages as neurons, cardiomyocytes and insulin-secreting cells. Moreover, these derived cells have been useful in different animal models. In this regard, insulin-secreting cells derived from R1 mouse embryonic stem cells restore blood glucose concentrations to normal when they are transplanted into streptozotocin-induced diabetic animals. These results show that diabetes could be among the first applications of stem cell therapy. [Diabetologia (2001) 44: 407-415]

Keywords Cell therapy, stem cells, diabetes, beta-cell, insulin secretion, islet of Langerhans, transplantation.
Cell therapy of diabetes mellitus has been mainly based on islet transplantation. Transplantation of pancreatic islet cells as a potential cure for diabetes has become a subject of intense interest and activity over the past two decades [1]. Islet transplantation involves isolation of islets and their transplantation through a simple injection into the umbilical vein, an operation devoid of the many potential complica-

Received: 8 August 2000 and in revised form: 6 November 2001

Corresponding author: $\mathrm{B}$. Soria, $\mathrm{MD}, \mathrm{PhD}$, Instituto de Bioingeniería, Universidad Miguel Hernández, Campus de San Juan, E-03550, Alicante, Spain

Abbreviations: EB, embryoid bodies; ECC, embryonal carcinoma cells; EGC, embryonic germ cells; ESC, embryonic stem cells; NIC, nicotinamide; PDX-1, homeodomain transcription factor pancreas/duodenum homeobox-1; SUR-1, sulphonylurea receptor; ENS ES, strain 129 embryonic-stem-cell line. tions of transplantating the pancreas [2]. Several barriers still delay, however, the success of this approach such as: (1) the diabetogenic effects of some immunosupressant agents [3]; (2) immunological rejection [4]; (3) the oncogenic effects of long-term immunosuppressive treatment and (4) insufficient number of beta cells transplanted [5]. A recent report has established that insulin-independence could be reached by combining a glucocorticoid-free immunosuppression with the transplantation of an adequate islet mass [6]. This successful example will increase the demand for human islets. Even with the new immunosuppressive therapy and less traumatic islet isolation procedures, which could be devised in the future, the shortage of donors is such that it will not be possible to meet the demand from all the patients with Type I (insulin-dependent) diabetes mellitus, however, consequently protocols to obtain insulin-secreting cells from other sources need to be developed. In this sense, the strategic knowledge 


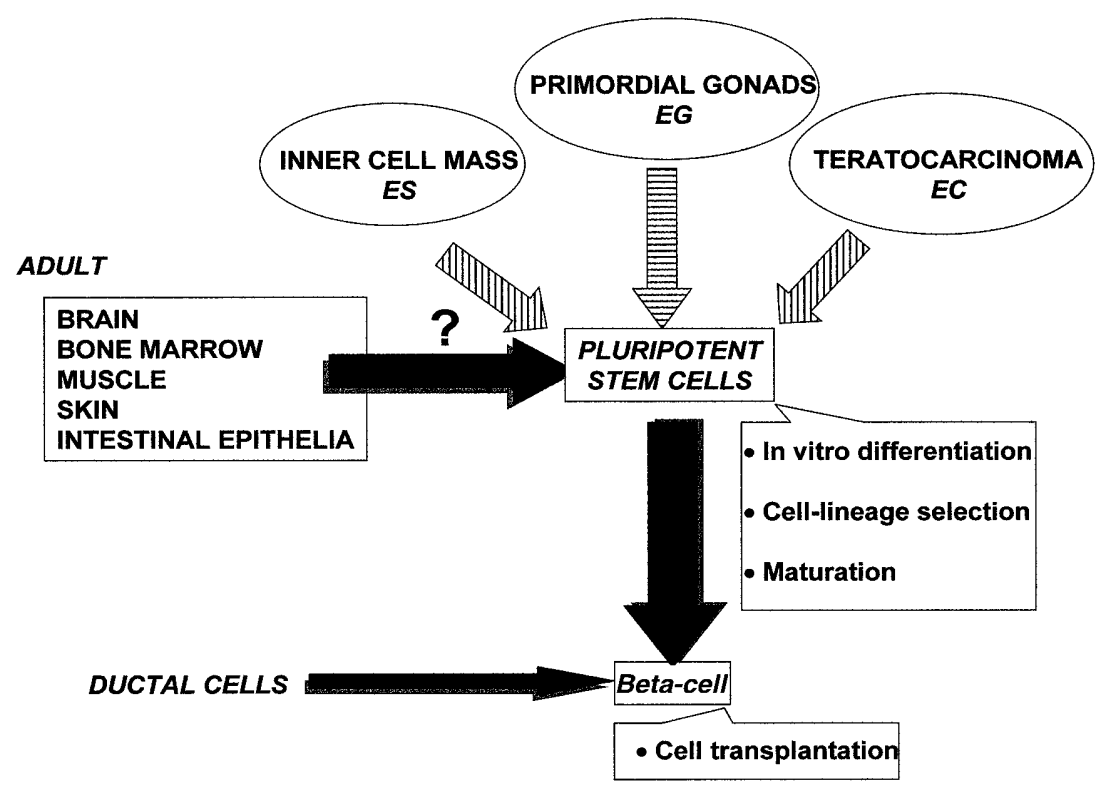

Fig. 1. Lineages of stem cells that can give rise to beta-cells. ES, embryonic stem; EG, embryonic germ; EC, embryonic carcinoma

achieved by molecular, cell and developmental biologists has supported the possibility of engineering islet cells to reconstruct pancreatic endocrine function [7].

A major goal for diabetes therapy is to genetically design an insulin-secreting artificial beta-cell. These beta-cells have potential advantages relative to islets isolated from cadaveric donors as a vehicle for insulin delivery: firstly, they can be grown at low cost and in essentially unlimited numbers under pathogen free conditions and secondly, because they are clonal by nature, those clones which retain functional features which are highly reproducible can be selected at will $[8,9]$. Most of the efforts have concentrated so far on the availability of beta-cell surrogates using tumour or transformed cell lines which can be modified to express the defective gene $[7,10,11]$. Use of tumoural cell lines, either of pancreatic or neuroendocrine origin in cell therapy of diabetes is restricted by several limitations [12-22]: firstly, tumoural cell lines retain their neoplastic nature; secondly, as a consequence of phenotypic instability and inadequate gene expression most beta-cell lines show maximum glucose responsiveness at considerably decreased glucose concentrations than those observed in normal islets and they tend to lose insulin biosynthesis and regulated secretion with the successive number of passages; and thirdly, cell lines present primitive differentiation features or even remnants of the parental cells. Proliferating islet cells of human origin have also been genetically modified to produce insulin-secreting cell lines [23-26]. In this regard, trans- fection of subconfluent monolayers of neonatal islet cells from patients suffering from persistent hyperinsulinaemic hypoglycaemia in infancy with the corresponding defective genes [sulphonylurea receptor (SUR-1), Kir6.2, homeodomain transcription factor pancreas/duodenum homeobox-1 (PDX-1)] results in a clonal cell line which shows glucose-sensitive insulin secretion within the normal range [27].

Stem cells, either pluripotent or committed to be beta cells, represent a potentially unlimited source of beta cells. Beta cells, in theory, could be derived from pluripotent stem cells [embryonic stem cells (ESC); embryonic germ cells (EGC) or teratocarcinoma, embryonal carcinoma cells (ECC)] or from their direct progenitor, the pancreatic ductal cells (Fig.1). Recently the mechanisms that control pancreatic development have been explained in part. In the early stages signals are derived from the notochord [fibroblast growth factor (FGF) 2 , activin $\beta \mathrm{B}$ ], and in later stages from mesenchymal which then induce proliferation and differentiation of pancreatic epithelial cells into islet cells [28]. The list of transcriptional factors implicated in pancreatic development identified so far include: Pdx-1, Pax-4 and Pax6, islet-1, beta2, NeuroD, Nkx2.2, Nkx6.1, Hexb9, neurogenin and p48. Knock-out mice lacking such factors show altered patterns in their pancreatic development. The capability to control islet cell differentiation, regeneration, growth and neogenesis has been discussed [7]. Major obstacles in the use of stem cells to reconstruct pancreatic function are: firstly, the need to design procedures to obtain, select and stimulate maturation of insulin-containing cells; secondly, the prevention of immunorejection, and thirdly, potential bioethical concerns. Designed cell lines could, however, have many advantages including unlimited cell supply; functional consistency; engineered immunoprotection that can avoid the onco- 


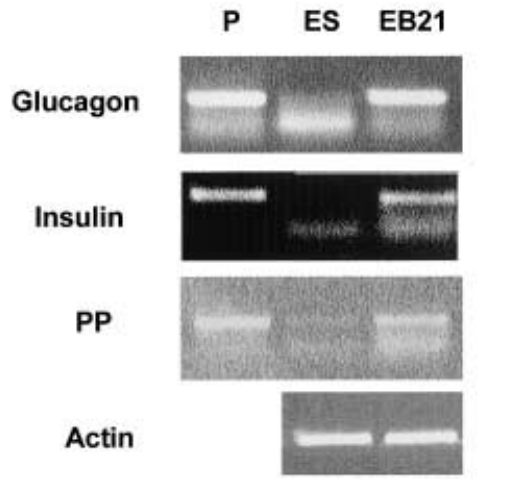

Fig. 2. RT-PCR analysis of gene expression in ENS embryonic stem cells allowed to spontaneously differentiate into embryoid bodies (day 21). P: adult mouse pancreas; embryonic stem: undifferentiated ENS embryonic stem cells; EB21: embryoid bodies from ENS embryonic stem cells at day 21 of culture

genic effects of long-term immunosuppresive treatment and in vitro genetic modifications.

\section{A shortcut to the future: from embryonic stem cells to insulin-containing cells}

Embryonic stem cells have the capacity to differentiate in vitro and in vivo into any adult tissue $[29,30]$ and thereby potentially permit the production of chimeras and identification of derivatives in any of the tissues in transgenic animals [31,32]. For obvious reasons, human ESC have not been checked for this property. Thus, ESC cells can be stimulated to differentiate in vitro into various cell types by removing various stimuli such as feeder layers and differentiation-inhibiting cytokines [33], or by adding specific differentiation-inducing substances [34-36]. Thus, based on developmental studies, biologists have produced well-defined differentiation protocols that can be used to guide embryonic stem cells into specific lineages, with variable success.

Directed differentiation. As indicated above, ESC differentiation occurs in vitro when the growth factor signals are in limited amounts. The exact nature of these signals is not known. In addition, it seems that gene expression under in vitro conditions does not follow the strict and regulated schedule observed during in vivo development. A number of protocols have been described to induce neuronal cells [37], adipocytes [38], smooth muscle myocytes [39], skeletal muscle myocytes and haematopoietic cells [40] from mouse ESC. In this regard, human ESC can undergo spontaneous differentiation under standard culture conditions, but the process of spontaneous differentiation is accelerated by suboptimal culture conditions [41, 42].

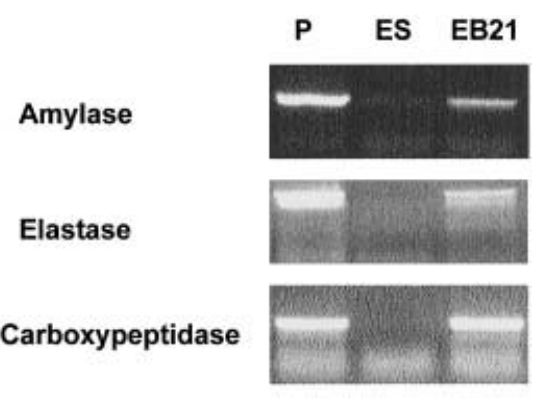

Endoderm-derived cells (gut, liver, exocrine and endocrine pancreas) have been very difficult to obtain. The sequence of events, growth factors, cell-tocell interactions, extracellular matrix factors and signalling pathways involved in the endoderm lineage pathway are beginning to be deciphered using a variety of molecular and developmental genetic approaches. Thus, there is still little knowledge on how to induce ESC into a particular endoderm path and the architectural complexity of epithelial tissue points to the importance of cell-to-cell interactions $[43,44]$. One solution is to partially reproduce the environmental conditions by coculturing pluripotent stem cells with the pancreatic primordial tissue which appears early in the mouse embryo development (E8.5-E9) or with adjacent germ layers, thus providing the soluble factors that induce early endoderm differentiation [45].

Embryoid bodies (EB) reproduce some of the conditions given for cell differentiation: they are polarised; there are cell-to-cell interactions; there exist asymmetric contacts and growth factors are being produced. Concerning pancreatic cells at day 12, embryoid bodies (EB) from a strain, 129 embryonicstem cell line (ENS ES) express transcripts of endocrine (i.e., insulin, glucagon and PP) and exocrine (i. e., amylase, elastase and carboxypeptidase) specific genes, suggesting that transcriptional factors involved in their regulation are functional in these embryonic stem cells (Fig.2). Finally, D3 embryonic stem cells when maintained in an undifferentiated state (in the presence of leukaemia inhibitory factor) were positive for insulin ( 3 out of 52 cells, Fig. 3A) and glucagon ( 3 out of 50 cells, Fig. 3B).

Cell selection methods. Even in improved conditions used to induce ESC differentiation, this process results in a mixture of cell types. The percentage of differentiated cells belonging to one phenotype remains very small (i.e. 0.1 to $0.5 \%$ ). Therefore, this mixed population is not suitable for transplantation or cell therapy and additional strategies are required to obtain pure populations of cells with the desired phenotypes. Selection of specific cell types could be based on the expressed phenotype (i. e. a membrane report- 


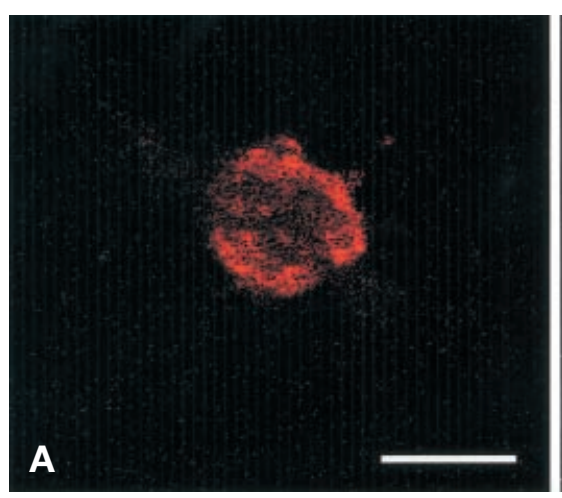

Fig.3 A, B. Marker expression of insulin and glucagon in undifferentiated embryonic stem (ES) cells. (A) Undifferentiated D3 embryonic stem cell stained with antibody to insulin (1/1000). (B) Undifferentiated D3 embryonic stem cell stained with antibody to glucagon (1/2000). Bars represent $10 \mu \mathrm{m}$

er protein) and fluorescence-activated cell-sorting selection of the desired cell population. A higher yield of differentiated cells might be achieved by applying genetic selection when a marker gene is expressed [46-48]. We have adapted this methodology for the selection of insulin-containing cells [8]. Our cell-trapping system consists of transfecting the embryonic stem (ES) cells with a chimeric construct, which functionally couples the regulatory region of the human insulin gene to a gene that confers resistance to a drug (i.e. the neomycin resistance gene) (Fig.4). Thus, those cells, which express the protein of interest, will also express the drug resistance gene. By a similar strategy murine cardiomyocytes have been obtained that form stable intracardiac grafts when transplanted into adult dystrophic mice [46], also bringing about the production of neural precursors [47] or forcing the expression of a transcription factor such as Oct3/4, thereby keeping embryonic stem cells in an undifferentiated state [48]. Another approximation for the genetic selection method is the transfection of ESC by gene encoding, the green fluorescent protein under the control of the cardiac $\alpha$-actin promoter [49]. Upon differentiation only cardiomyocytes expressed the green fluorescent protein, it being possible to isolate them by cell sorting.

Cell maturation. Altogether these data indicate that specific and relative pure cell types can be isolated from in vitro differentiated ESC. In some cases, however, these differentiated cells need to undergo a final maturation process to be completely functional. This was the case with the islet progenitor cell-derived islets [9] or the embryonic stem-derived insulin-secreting cells [8]. In both situations, the cells had a low insulin content and an inefficient release of insulin. Thus, it is very important to understand
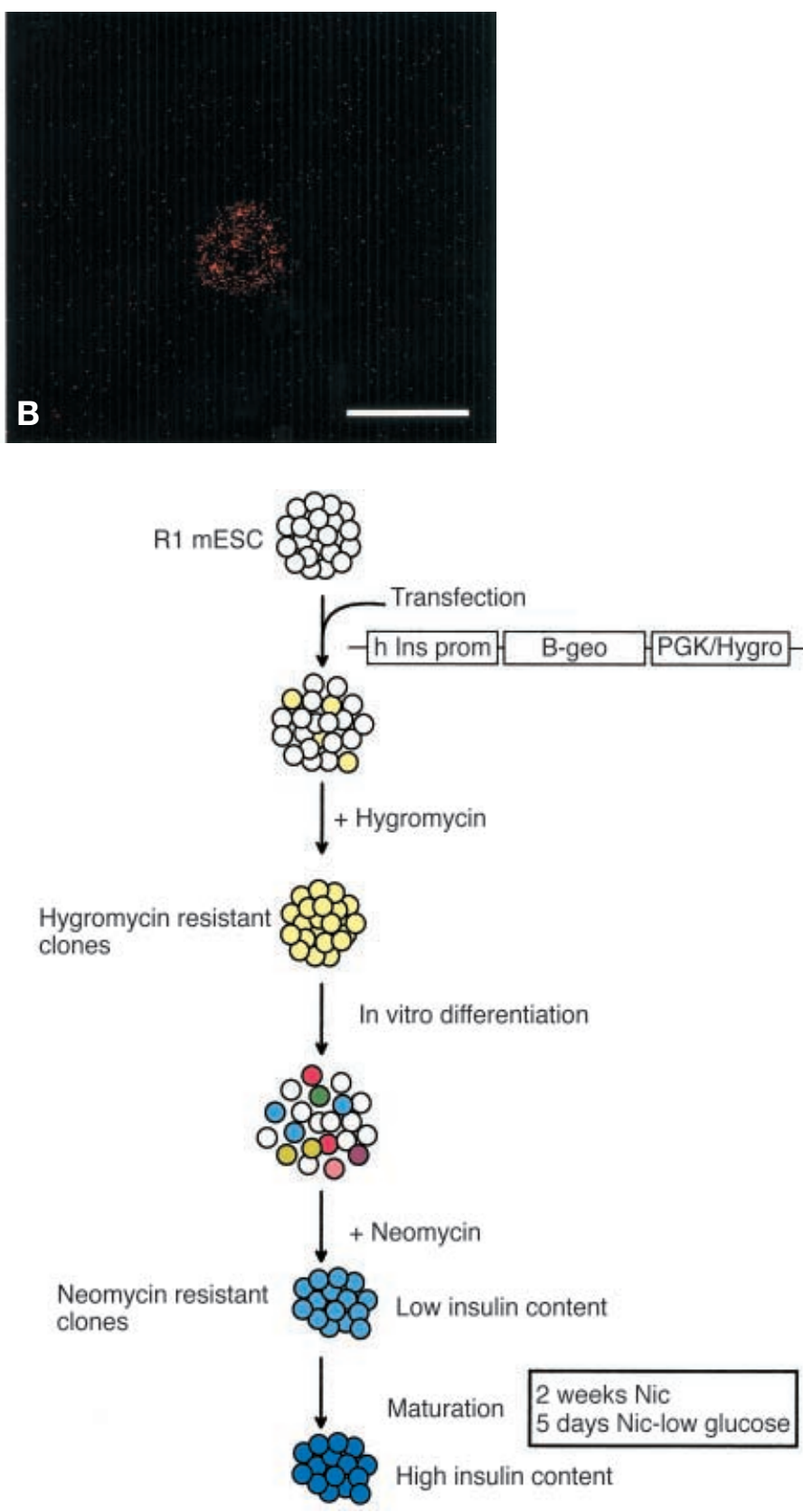

Fig. 4. Flow diagram for the in-vitro pathway from embryonic stem cell to transplantable insulin-containing cells

the factors, which provide a permissive in vitro environment allowing islet neogenesis from duct cells, acinar cells or stem cells to further mature and/or differentiate into fully functional islets with maximum insulin production capacity. Among them are vascular endothelial growth factor [50], hepatocyte growth factor [51], transforming growth factor [52], islet neogenesis-associated protein [53], regenerating gene-1 [54], insulin-like growth factor [55], gastrin [56], epidermal growth factor [57] and activin A and betacellulin [58].

The majority of the maturation protocols are based on studies from fetal islets [59], rat pancreatic 

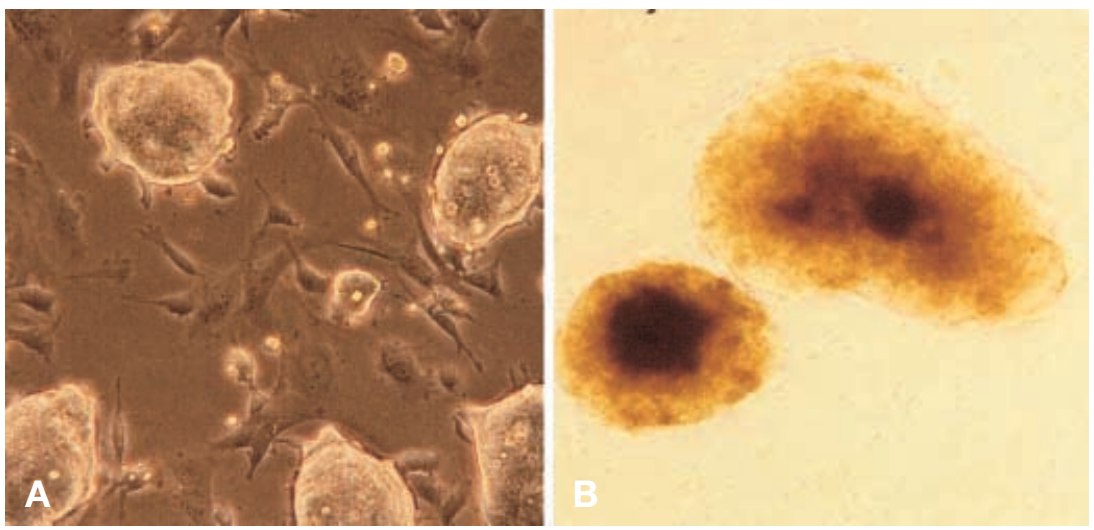

Fig.5. Phase contrast images of R1 embryonic stem cells and their differentiated progeny. (A) Undifferentiated R1 embryonic stem colony growing on a feeder layer of mitotically inactivated mouse STO fibroblasts. (B) Insulin-secreting cells (clone IB/3x-99) after G418 selection and final maturation proccess by culturing for two weeks in $10 \mathrm{mmol} / \mathrm{l}$ nicotinamide and another week in $10 \mathrm{mmol} / \mathrm{l}$ nicotinamide plus $5 \mathrm{mmol} / \mathrm{l}$ glucose. Bars represent $100 \mu \mathrm{m}$

regeneration [60] and adult pancreatic duct cells [61]. Some of these protocols used nicotinamide as a differentiation factor $[62,63]$. These studies, together with the fact that glucose is a major modulator of gene expression in beta-cells and that sustained hyperglycaemia can produce considerable phenotypic changes which altered the pattern of beta-cell differentiation and insulin secretion [15, 64-66], led us to follow a maturation strategy mainly based on the use of nicotinamide and non-stimulatory glucose concentrations (Fig. 5) [8]. Over 2 weeks culture in $10 \mathrm{mmol} / \mathrm{l}$ nicotinamide and another week in $10 \mathrm{mmol} / \mathrm{l} \mathrm{nicoti-}$ namide plus $5 \mathrm{mmol} / \mathrm{l}$ glucose the insulin content of the cells increased 20 -fold and the cells showed a good secretagogue-induced insulin response to different secretagogues [8]. Recently, it has been shown that human ductal tissue could be expanded in culture and then directed to differentiate in vitro [61]. The step-by-step maturation protocol consist of the following: (1) adherent cells after 1 to 4 days of culture are expanded for up to 1 week until they form monolayers, (2) the media is changed to serum-free DMEM with $8 \mathrm{mmol} / \mathrm{l}$ glucose, ITS supplement (insulin + transferrin + selenium), $10 \mathrm{mmol} / \mathrm{l}$ nicotinamide and keratonicyte growth factor for 1 to 2 more weeks, (3) cells are layered with Matrigel, a commercial preparation of murine basement membrane. This procedure yields a high proportion of insulin positive cells which respond to glucose.

\section{Stem-derived cell replacement therapies}

At present, the most urgent problem in transplantation is the lack of suitable donors. One alternative to organ transplantation is ESC-based cell therapy. This strategy is based on the idea that pluripotent stem cells can be used to produce large numbers of cells that can be genetically modified in vitro to differentiate along a given pathway, thus obviating the need for fetal tissues. Obviously, the clinical targets of cell therapy are neurodegenerative disorders (Alzheimer and Parkinson's diseases), diabetes, spinal cord injuries, cardiovascular diseases, osteoporosis, autoimmune diseases, cancer, severe burns, muscular dystrophies, haematopoietic repopulation and birth defects.

At the experimental stage, this concept needs to be proved by using animal models of disease to which cell therapy can be applied to show its therapeutic benefit. Until now, only three groups of investigators have gone this far in using ESC. One group has used differentiation and cell selection protocols to generate D3 ESC-derived cardiomyocytes that formed stable intracardiac grafts for as long as 7 weeks after implantation [46, 47]. Another group showed that immature nerve cells generated from mouse embryonic stem cells and transplanted into damaged spinal cords of rats partially restored the animals' spinal cord function [68]. In addition, using a similar approach we have produced an insulin-secreting cell derived from R1 mouse embryonic stem cells that restores blood glucose concentrations to normal when transplanted into streptozotocin-induced diabetic animals. The animals transplanted with the final clone IB/3x-99 corrected the hyperglycaemia within 1 week (Fig. 6A), restored body weight in 4 weeks (Fig. 6B) and showed normal blood glucose concentrations after a challenge meal similar to that of control mice $(n=10)$ [8]. Notably, 3 mice were normoglycaemic for more than 12 months (data not shown). In addition, a recent report showed that functional islets derived from ductal structures of non-obese diabetic (NOD) mice could reverse insulin-dependent diabetes when transplanted into diabetic non-obese mice [9]. 


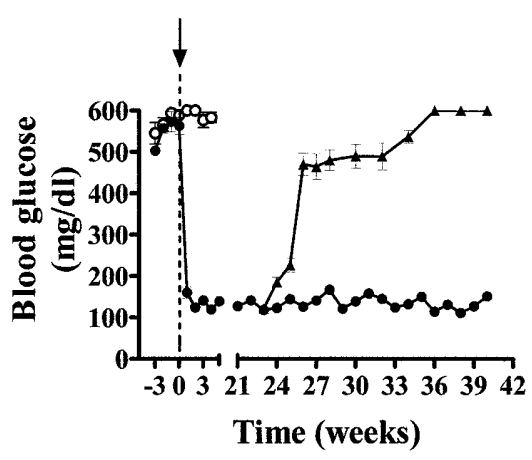

Fig. 6. Changes in blood glucose concentrations (A) and body weight (B) after implantation of IB/3x-99 cells in hyperglycaemic animals. (A) Blood glucose concentrations in sham-operated diabetic mice $(\bigcirc)$, embryonic stem-implanted mice $(\mathbf{O})$ and embryonic stem-implanted mice that became hyperglycaemic (A). (B) Body weight in sham-operated diabetic mice $(\bigcirc)$ and embryonic stem-implanted mice $(\mathbf{O})$. Arrow indicates the implantation day (shown as week 0). Values are means \pm SEM. Adapted from [8] with permission

Before the transplantation of embryonic stem-derived cells to humans can be accomplished, several theoretical and experimental problems must be overcome. Firstly, equilibrium has to be attained between the proliferative capacity, lack of tumourigenicity, and differentiation potential. Ideally, the molecular basis of such a delicate equilibrium should be unravelled so that it can be used in a variety of situations. In our study, the construction engineered and the maturation strategy followed rendered clones which were not tumourigenics but whose proliferative potential was still suboptimal: approximately $40 \%$ of the animals receiving transplants developed hyperglycaemia 12 weeks after transplantation probably because of the limited lifespan of the implanted cell cluster [8]. Secondly, any cells used in transplantation would need to be autologous or immunologymasked. The immunological destruction of the graft could be at the origin of the reversal of normoglycaemia observed in some of our mice implanted with ESC. Thirdly, it is important to identify the appropriate site integration of selection vectors to achieve high expressions of the transgenes thus allowing us to select a pure population of cells. In our case, the transgenes were appropriately expressed even 4 months after the engraftment in diabetic animals, as shown by the X-Gal staining in IB/3X-99 cells $(n=3$, Fig. 7A). Pure populations of cell types is a prerequisite because introduction of contaminating pluripotent ESC during transplantation might give rise to teratomas [8]. Finally, cells need to have homogeneous and stable phenotypes. Immunohistochemistry studies of the spleen of normoglycaemic animals showed insulin-expressing IB/3x-99 cells 4 months after engraftments ( $n=3$, Fig. 7B).

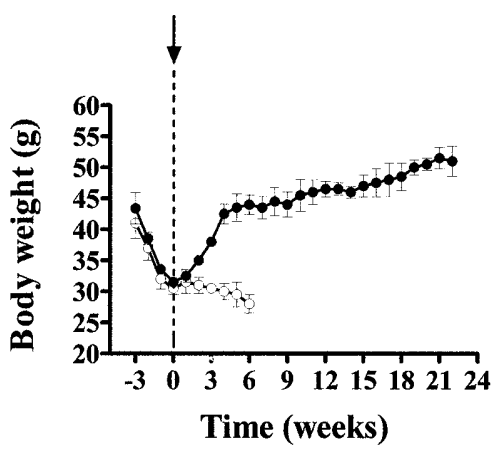

The studies using ESC $[46,68,8]$ show that specific and relatively pure cell types can be isolated from differentiated ESC in vitro and successfully transplanted. Although it is not clear if human ESC can be genetically modified and specific cell types isolated, the development of human embryonic stem $\mathrm{C}$ lines $[41,42]$ should facilitate their use for cell therapy to become a reality.

\section{Future perspectives in stem cell research}

Apart from reproductive cloning, the creation of Dolly the cloned sheep [69] has opened two main possibilities. Theoretically, nuclear transfer from a patient's cell to a recipient enucleated cell (either oocyte, embryonic stem or EG cells) would make it possible to obtain "customised" embryonic stem cells that could be induced to differentiate into human tissues and cell lineages useful for cell therapy of diseases like diabetes mellitus. Conceptually, given that nuclear DNA in adult somatic tissues can be reprogrammed to regain its pluripotentiality [70], it should be possible in principle to obtain pluripotential stem cells from adult tissues. This hitherto unrecognised plasticity could be exploited to generate cells and tissues for autologous grafts. Whereas these notions are not likely, the newly discovered versatility of some somatic stem cells invites us to test this possibility for stem cell therapeutics. In the new method, cells or nuclei will only be temporally committed and their localisation in a totipotent environment would induce these cells to abandon the previous stage and acquire a new developmental phenotype. In therapeutic terms, it might be irrelevant whether these cells are resident totipotent stem cells or whether they differentiate into a totipotent stage, provided that they are used to generate cells and tissues for transplantation. Clearly, the exploitation of both genetic and epigenetic factors will be at the basis of such developments.

Recently, several reports have appeared that add new insights and perspectives to the prevailing concepts of somatic stem cell potentials. There are suggestions that the functional plasticity of somatic tissue-derived stem cells might be greater than expect- 


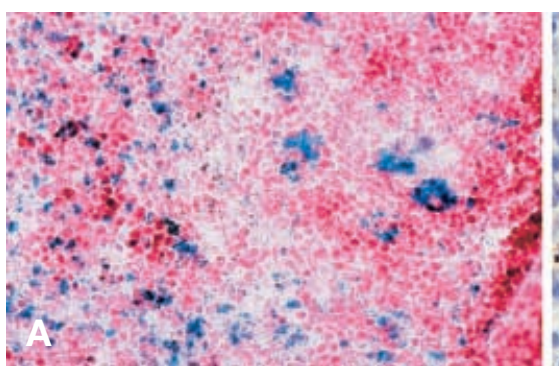

Fig. 7 A, B. IB/3x-99 cells express the construction, and produce insulin 4 months after their engraftment in hyperglycaemic animals. (A) X-Gal staining of IB/3x-99 cells 4 months after their transplantation into the spleen. (B) Insulin-producing cells visualised with an antibody against insulin (1/500) in the spleen of a 4 months normoglycaemic animal. Bars represent $100 \mu \mathrm{m}$

ed. Adult stem cells from mouse brain can pass to the blood stream and bone marrow and become mature blood cells [71]. Similarly, stem-cell populations originally obtained from muscle show a robust transplantable haematopoietic activity [72]. More recently, it has been shown that a human adult haematopoietic stem-cell population is capable of yielding an epithelial lineage (adult human liver cells) [73]. Once it is accepted that cells from adult subjects can be reprogrammed to express a distinct phenotype, the existence of putative pluripotential stem cells in adult tissues will be the next step to establish. Our group has observed that cells isolated from adult intestine, when appropriately cultured, expressed markers from each of the three embryonic germ layers (data not shown). Apart from circumventing the ethical dilemmas surrounding research on embryonic and fetal stem cells, adult stem cells possess another advantage which is that they could be obtained from the patient, thus allowing autotransplantation. Theoretical drawbacks, however, such as a shorter lifespan (making them less suitable for medical applications), which might limit their use, have to be addressed.

In conclusion, we are still far from understanding the processes involved in stem cell self-renewal and differentiation, yet the potential uses for stem cells seem endless. Nevertheless, we are aware that a major difference exists between autoimmune diabetes, which is treatable with insulin, and life-threatening diseases like kidney or heart failure. Before cell therapy can be applied the risks and benefits have to be properly balanced. For example, long-term threatment with immunosuppresive agents in patients with long life expectancy could result in an increased rate of malignancies. In recent years, stem cell biology has been advancing at an incredibly rapid pace and evidence is accumulating that shows the enormous potential of stem cell technology, which might hold the answer to cure some devastating diseases such as diabetes.

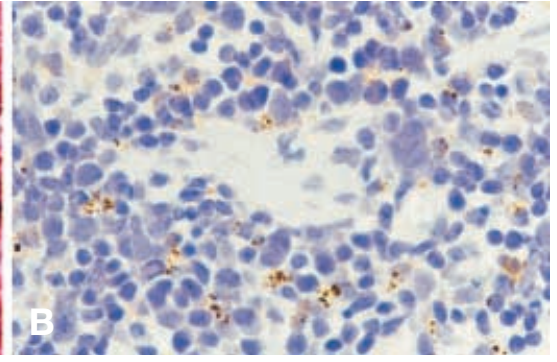

Acknowledgements. These studies have been partially supported by grants from the State Secretary of Universities and Research, Spain (PM98-0105 and PM99-0142); the MaratóTV3 Foundation (99-1210); 2000 EASD/Eli Lilly Research Fellowship; Juvenile Diabetes Foundation (JDFI 1-2000-575) and Salud 2000 Foundation. We are grateful to Dr. F.X. Real for helpful comments on the manuscript and Dr. G. Berná for designing Figure 4. Finally we are particularly grateful to Dr. E. Montanya for his help with immunohistochemical experiments. The text was revised by I. Ward. Technical support of E. Fuster is greatly acknowledged.

\section{References}

1. Sachs DH, Bonner-Weir S (2000) New islets from old. Nat Med 6: 250-251

2. Stratta RJ, Taylor RJ, Larsen JL, Cushing K (1995) Pancreas transplantation. Ren Fail 17: 323-337

3. Martin F, Bedoya FJ (1990) Short term effects of cyclosporin $\mathrm{A}$ on secretagogue induced insulin release by isolated islets. Transplantation 50: 551-553

4. Gil RG (1999) Antigen presentation pathways for immunity to islet transplant. Relevance to immunoisolation. Ann N Y Acad Sci 875: 255-260

5. Oberholzer J, Triponez F, Magez R et al. (2000) Human islet transplantation: lessons form 13 autologous and 13 allogeneic transplantations. Transplantation 69: 11151123

6. Shapiro AMJ, Lakey JRT, Ryan EA et al. (2000) Islet transplantation in seven patients with Type I Diabetes Mellitus using a glucocorticoid-free immnuosuppressive regimen. N Engl J Med 343: 230-238

7. Soria B, Andreu E, Berná G, Fuentes E et al. (2000) Engineering pancreatic islets. Pflügers Arch 440: 1-18

8. Soria B, Roche E, Berná G, León-Quinto T, Reig JA, Martín F (2000) Insulin-secreting cells derived from embryonic stem cells normalize glycemia in streptozotocin-induced diabetic mice. Diabetes 49: 157-162

9. Ramiya VK, Maraist M, Arfors KE, Schatz DA, Peck AB, Cornelius JG (2000) Reversal of insulin-dependent diabetes using islets generated "in vitro" from pancreatic stem cells. Nat Med 6: 278-282

10. Ferber S, Heimberg H, Brownlee M, Colton C (1997) Surrogate beta cells. Diabetologia 40: B39-B43

11. Efrat S (1998) Prospects for gene therapy of insulin-dependent diabetes mellitus. Diabetologia 41: 1401-1409

12. Gazdar Af, Chick Wl, Oie HK et al. (1980) Continuous, clonal, insulin- and somatostatin-secreting cell lines established from a transplantable rat islet cell tumor. Proc Natl Acad Sci USA 77: 3519-3523

13. Clark SA, Burnham BL, Chick WL (1990) Modulation of glucose-induced insulin secretion from a rat clonal betacell line. Endocrinology 127: 3940-3948 
14. Asfari M, Janjic D, Meda P, Li G, Halban PA, Wollheim CB (1992) Establishment of 2-mercaptoethanol-dependent differentiated insulin-secreting cell lines. Endocrinology 130: $167-178$.

15. Roche E, Farfari S, Witters LA et al. (1997) Induction by glucose of genes coding for glycolytic enzymes in a pancreatic beta-cell line (INS-1). J Biol Chem 272: 3091-3098

16. Efrat S, Leiser M, Surana M et al. (1993) Murine insulinoma cell line with normal glucose-regulated insulin secretion. Diabetes 42: 901-907

17. Knaack D, Fiore DM, Suran M et al. (1994) Clonal insulinoma cell line which stably maintains correct glucose responsiveness. Diabetes 43: 1413-1417

18. Efrat S, Linde S, Kodof $\mathrm{H}$ et al. (1988) Insulin synthesis in a clonal cell line of simian virus 40-transformed hamster pancreatic beta cells. Proc Natl Acad Sci USA 85: 9037-9041

19. Efrat S, Fusco-DeMane D, Lemberg H, Emran OA, Wang $\mathrm{S}$ (1995) Conditional transformation of a pancreatic $\beta$-cell line derived from transgenic mice expressing a tetracycline-regulated oncogene. Proc Natl Acad Sci USA 92: 3576-3580

20. Hughes SD, Johnson JH, Quaade C, Newgard CB (1992) Engineering of glucose-stimulated insulin secretion and biosynthesis in non-islet cells. Proc Natl Acad USA 89: 688-692

21. Motoyoshi S, Shirotani T, Araki E et al. (1998) Cellular characterization of pituitary adenoma cell line (AtT20 cell) transfected with insulin, glucose transporter Type II (Glut2) and glucokinase genes: Insulin secretion in response to physiological concentrations of glucose. Diabetologia 41: 1492-1501

22. Moore HP, Walker MD, Lee F, Kelly RB (1983) Expressing a human proinsulin cDNA in a mouse ACTH-secreting cell. Intracellular storage, proteolytic processing, and secretion on stimulation. Cell 35: 531-538

23. Soldevila G, Buscema M, Marini V et al. (1991) Transfection with SV40 gene of human pancreatic endocrine cells. J Autoimmun 4: 381-396

24. Wang S, Beattie GM, Mally MI et al. (1997) Isolation and characterization of a cell line from the epithelial cells of the human fetal pancreas. Cell Transplant 6: 59-67

25. Wang S, Beattie GM, Mally MI et al. (1997) Analysis of a human fetal pancreatic islet cell. Transplant Proc 29: 2219

26. Levine F, Wang S, Beattie G et al. (1995) Development of a cell line from the human fetal pancreas. Transplant Proc 27: 3410

27. McFarlane WM, Chapman JC, Shepherd RM et al. (1999) Engineering a glucose-responsive human insulin-secreting cell line from islets of Langerhans isolated from a patient with persistent hyperinsulinemic hypoglycemia of infancy. J Biol Chem 274: 34059-34066

28. Scharfmann R (2000) Control of early development of the pancreas in rodents and humans: implications of signals from the mesenchyme. Diabetologia 43: 1083-1092

29. Till JE, McCulloch EA (1961) A direct measurement of the radiation sensitivity of normal mouse bone marrow cells. Radiat Res 14: 1419-1430

30. Wobus A, Holzhausen H, Jäkel P, Schöneich J (1984) Characterization of a pluripotent stem cell line derived from a mouse embryo. Exp Cell Res 152: 212-219

31. Nagy A, Gocza E, Diaz EM et al. (1990) Embryonic stem cells alone are able to support fetal development in the mouse. Development 110: 815-821

32. Wang ZQ, Kiefer F, Urbanek P, Wagner EF (1997) Generation of completely embryonic stem cell-derived mutant mice using tetraploid blastocyst injection. Mech Dev 62: 137-145

33. Pedersen RA (1994) Studies of in vitro differentiation with embryonic stem cells. Reprod Fertil Dev 6: 543-552

34. Wobus AM, Rohwedel J, Maltsev V, Hescheler J (1994) In vitro differentiation of embryonic stem cells into cardiomyocytes or skeletal muscle cells is specifically modulated by retinoic acid. Roux's Archives of Developmental Biology 204: 36-45

35. Wobus AM, Kaomei G, Shan MC et al. (1997) Retinoic acid accelerates embryonic stem cell-derived cardiac differentiation and enhances development of ventricular cardiomyocytes. J Mol Cell Cardiol 29: 1525-1529

36. Rohwedel J, Guan K, Wobus AM (1999) Induction of cellular differentiation by retinoic acid in vitro. Cells Tissues Organs 165: 190-202

37. Gottlieb DI, Huettner JE (1999) An in vitro pathway from embryonic stem cells to neurons and glia. Cell Tissues Organs 165: $165-172$

38. Dani C (1999) Embryonic stem cell-derived adipogenesis. Cells Tissues Organs 165: 173-180

39. Drabb M, Haller H, Bychkov R et al. (1997) From totipotent embryonic stem cells to spontaneously contracting smooth muscle cells: a retinoic acid and db-cAMP in vitro differentiation model. FASEB J 11: 905-915

40. Wiles MV, Keller G (1991) Multiple hematopoietic lineages develop from embryonic stem (embryonic stem) cells in culture. Development 111: 259-267

41. Thomson JA, Itskovitz-Eldor J, Shapiro SS et al. (1998) Embryonic stem cell lines derived from human blastocysts. Science 282: 1145-1147

42. Reubinoff BE, Pera MF, Chui-Yee F, Trounson A, Bongso A (2000) Embryonic stem cell lines from human blastocysts: somatic differentiation in vitro. Nature Biotechnol 18: 399-404

43. Ahlgren U, Pfaff SL, Jesell TM, Edlund T, Edlund H (1997) Independent requirement for ISL 1 in formation of pancreatic mesenchyme and islet cells. Nature 385: 257-260

44. Duluc I, Freund JN, Leberquier C, Kedinger M (1994) Fetal endoderm primarily holds the temporal and positional information required for mammalian intestinal development. J Cell Biol 126: 211-221

45. Wells JM, Melton DA (2000) Early mouse endoderm is patterned by soluble factors from adjacent germ layers. Development 127: 1563-1572

46. Klug MG, Soonpaa MH, Koh GY, Field LJ (1996) Genetically selected cardiomyocytes from differentiating embryonic stem cells form stable intracardiac grafts. J Clin Invest 98: 216-224

47. Li M, Pevny L, Lovell-Badge R, Smith A (1998) Generation of purified neural precursors from embryonic stem cells by lineage selection. Curr Biol 8: 971-974

48. McWhir J, Schnieke AE, Ansell R et al. (1996) Selective ablation of differentiated cells permits isolation of embryonic stem cell lines from murine embryos with a non-permissive genetic background. Nat Genet 14: 223-226

49. Kolossov E, Fleischmann BK, Liu Q et al. (1998) Functional characteristics of embryonic stem cell-derived cardiac precursor cells identified by tissue-specific expression of the green fluorescent protein. J Cell Biol 143: 2045-2056

50. Rooman I, Schuit F, Bouwens L (1997) Effect of vascular endothelial growth factor on growth and differentiation of pancreatic ductal epithelium. Lab Invest 76: 225-232

51. Otonkoski T, Beattie GM, Rubin JS, Lopez AD, Baird A, Hayek A (1994) Hepatocyte growth factor/scatter factor has insulinotropic activity in human fetal pancreatic cells. Diabetes 43: 947-953 
52. Wang TC, Bonner-Weir S, Oates PS et al. (1993) Pancreatic gastrin stimulates islet differentiation of the TGF-alpha induced ductular precursor cells. J Clin Invest 92: 1349-1356

53. Rafaeloff R, Pittenger GL, Barlow SW et al. (1997) Cloning and sequencing of the pancreatic islet neogenesis associated protein (INGAP) gene and its expression in islet neogenesis in hamsters. J Clin Invest 99: 2100-2109

54. Watanabe T, Yonemura Y, Yonekura H et al. (1994) Pancreatic- beta-cell replication and amelioration of surgical diabetes by Reg protein. Proc Natl Acad Sci USA 91: 3589-3592

55. Smith FE, Rosen KM, Villa-Komaroff L, Weir GC, Bonner-Weir S (1991) Enhanced insulin-like growth factor I gene expression in the regenerating rat pancreas. Proc Natl Acad Sci USA 88: 6152-6156

56. Wang RN, Rehfeld JF, Nielssen FC, Kloppel G (1997) Expression of gastrin and transforming growth factor-alpha during duct to islet cell differentiation in the pancreas of duct-ligated adult rats. Diabetologia 40: 887-893

57. Verme TB, Hootman SR (1990) Regulation of pancreatic duct epithelial growth in vitro. Am J Physiol 258: G833G840

58. Mashima H, Ohnishi H, Wakabayashi K et al. (1996) Betacellulin and activin A coordinately convert amylase-secreting pancreatic AR42J cells into insulin-secreting cells. J Clin Invest 97: 1647-1654

59. Otonkoski T, Mally MI, Hayek A (1994) Opposite effects of beta-cell differentiation and growth on reg expression in human fetal pancreatic cells. Diabetes 43: 1164-1166

60. Bonner-Weir S, Baxter LA, Schupping GT, Smith FE (1993) A second pathway for regeneration of adult exocrine and endocrine pancreas. A possible recapitulation of embryonic development. Diabetes 93: 1715-1720

61. Bonner-Weir S, Taneja M, Weir GC et al. (2000) In vitro cultivation of human islets from expanded ductal tissue. Proc Natl Acad Sci USA 97: 7999-8004

62. Otonkoski T, Beattie GM, Mally MI, Ricordi C, Hayek A (1993) Nicotinamide is a potent inducer of endocrine dif- ferentiation in cultured human fetal pancreatic cells. J Clin Invest 92: 1459-1466

63. Sjoholm A, Korsgren O, Andersson A (1994) Polyamine requirement in nicotinamide-stimulated beta-cell differentiation in fetal porcine islet-like clusters. Endocrinology 135: 1559-1565

64. Susini S, Roche E, Prentki M, Schlegel W (1998) Glucose and glucoincretin peptides synergize to induce c-fos, c-jun, junB, zif268, nur-77gene expression in pancreatic beta(INS-1) cells. FASEB J 12: 1173-1182

65. Roche E, Farfari S, Witters LA et al. (1998) Long-term exposure of beta-INS cells to high glucose concentrations increases anaplerosis, lipogenesis, and lipogenic gene expression. Diabetes 47: 1086-1094

66. Jonas JC, Sharma A, Hasenkap W et al. (1999) Chronic hyperglycemia triggers lossof pancreatic beta-cell differentiation in an animal model of diabetes. J Biol Chem 274: 14112-14121

67. Koh GY, Klug MG, Soonpaa MH, Field LJ (1993) Differentiation and long-term survival of $\mathrm{C} 2 \mathrm{C} 12$ myoblast grafts in heart. J Clin Invest 92: 1548-1554

68. McDonald JW, Liu XZ, Qu I et al. (1999) Transplanted embryonic stem cells survive, differentiate and promote recovery in injured rat spinal cord. Nat Med 5: 1410-1415

69. Wilmut I, Schnieke AE, McWhir J, Kind AJ, Campbell KHS (1997) Viable offspring derived from fetal and adult mammalian cells. Nature 385: 810-813

70. Bjornson CRR, Rietze RL, Reynolds BA, Magli MC, Vescovi AL (1999) Turning brain into blood: a hematopoietic fate adopted by adult neural stem cells in vivo. Science 283: 534-537

71. Jackson KA, Mi T, Goodell MA (1999) Hematopoietic potential of stem cells isolated from murine skeletal muscle. Proc Natl Acad Sci USA 96: 14482-14486

72. Blau HM, Baltimore D (1991) Differentiation requires continuous regulation. J Cell Biol 112: 781-783

73. Alison MR, Poulsom R, Jeffery R et al. (2000) Hepatocytes from non-hepatic adult stem cells. Nature 406: 257 